\title{
TSUNAMI DAMAGES OF NAKOSO COAST DUE TO THE 2011 TOHOKU TSUNAMI
}

\author{
Shinji Sato ${ }^{1}$, Haijiang Liu ${ }^{1}$, Satoshi Takewaka ${ }^{2}$, Hisamichi Nobuoka ${ }^{3}$ and Shin-ichi Aoki ${ }^{4}$ \\ A post-2011 Tohoku earthquake tsunami survey was conducted at the Nakoso Coast, Fukushima Prefecture, Japan, \\ on Mar 24-25 and Apr 1-2, 2011. Spatial distribution of the tsunami inundation height, together with the seawall \\ height and damages, was investigated. We found a sharp contrast of tsunami damages within the target area; tsunami \\ damage is the most serious in the north region (north of the Samegawa River) where seawalls with different heights \\ played diverse roles for protection of local community. A relatively high seawall in this region kept intact after \\ tsunami attack, and protected the lee side human properties; whereas, $71 \%$ of the low seawalls were broken during \\ the tsunami and the disaster developed in the corresponding sheltered area. A sharp contrast at the boundary of these \\ two types of seawalls was observed. Behind the high seawall, the tsunami intensity and velocity were significantly \\ reduced and the inundation depth is only $0.6 \mathrm{~m}$. Nevertheless, tsunami intensity was enhanced in the seawall-broken \\ area with an inland inundation depth being $4.7 \mathrm{~m}$, which ruins away the local houses. In the middle region between \\ the Samegawa River and the Bindagawa River, the high seawall survived from the tsunami attack. We confirmed that \\ the coastal pine tree forest, serving as a buffer zone, played a significant role in reducing the tsunami height \\ approximately by $4 \mathrm{~m}$ within a cross-shore distance of $230 \mathrm{~m}$. To the south of the Bindagawa River, the tsunami \\ damage is the mildest due to the protection by the robust high seawall as well as high elevation of land topography.
}

Keywords: coastal disaster; tsunami; seawall; flooding

\section{INTRODUCTION}

At 14:46 on March 11, 2011 (JST), a magnitude 9.0 earthquake occurred near the northeast coast of Japan, resulted from thrust faulting on or near the subduction zone plate boundary between the Pacific and the North America Plates. This earthquake induced a tragic tsunami which severely destroyed Japanese Pacific coast, as well as a wide range of localities around the Pacific Ocean. According to the Tohoku Earthquake Tsunami Information (a web page by the Joint Survey Group, 2011), the measured maximum tsunami run-up height is even close to $40 \mathrm{~m}$ at some specified locations on the Sanriku Coast. This tsunami is considered as one of the biggest tsunami events (if not the biggest) within the last several hundred years in Japan. Tremendous damages on regional infrastructures, together with the significant personal casualties, are induced by this terrific tsunami attack.

In this paper, the post-tsunami survey result at the Nakoso Coast, Fukushima Prefecture, Japan, is presented, which includes the spatial distribution of the tsunami inundation height, the coastal seawall elevation, as well as the change in beach topography in the corresponding study area. Various posttsunami seawall situations tell different stories of these coastal defense structures for protection of local community. Survey on the spatial distribution of tsunami inundation height also reveals the efficiency of coastal forest as a buffer zone against the tsunami attack.

\section{STUDY AREA AND FIELD SURVEY}

In this study, we are focusing on the Nakoso coast located at the south of Fukushima Prefecture, Japan, which is a sandy pocket beach facing to the Pacific Ocean. Figure 1 presents the general layout of the area. It is an arc-shaped concave beach with a length approximate $7 \mathrm{~km}$ and isolated by two headlands, Cape Ryuugu on the north end and Cape Unoko on the south end. The Samegawa River, as the most predominant river in this area, originates from the Abukuma mountains with a catchment area of $600 \mathrm{~km}^{2}$ and a route length of $58 \mathrm{~km}$, and flows on the southern part of Fukushima Prefecture reaching the Nakoso coast. About $1.5 \mathrm{~km}$ south of the Samegawa River, a small river, the Bindagawa River, is located. A comprehensive field study on this corresponding area was conducted in 2004 to investigate the gross sediment movement and long-term beach evolution process based on the aerial photography, the river and coast survey data, and the sand sample mineral composition analysis (Sato et al., 2000). A power plant is located to the north of the Samegawa River mouth. Yellow area in Figure 1 represents the area inundated by the tsunami, which covers a wide area in Iwama and Ooshima Districts located to the north of the Samegawa River, Suga District between the Samegawa River and the Bindagawa River and the Sekita District located to the south of the Bindagawa River.

\footnotetext{
${ }^{1}$ Department of Civil Engineering, The University of Tokyo, 7-3-1, Hongo, Bunkyo-ku, Tokyo, 113-8656, Japan

2 Department of Systems and Information Engineering, University of Tsukuba, Tsukuba, Ibaraki, 305-8573, Japan

${ }^{4}$ Department of Civil Engineering, Osaka University, Osaka, Osaka, Japan
} 
Two weeks after the tsunami attack, we carried out field survey twice on March 24-25 and April 12, 2011. On March 24-25, survey was focused on the general information of the tsunami damage, e.g., tsunami inundation height and run-up height, which were identified from the water mark on the wall or window of remaining buildings and the diffused debris on the slope ground, respectively. On April 1-2, attention was paid to the coastal seawall height distribution and the relationship between the inundation area and the inland topography. During these two surveys, interviews to the local residents were also performed to obtain the first-hand testimony related to the intraday tsunami arriving time, direction and other information. It was proved from the local residents that at least five tsunamis attacked this region in which the third and fifth ones were the largest two. It was observed that the first and the second tsunamis came from the north direction, whereas the third or the fifth tsunami with a large wave height came from the south. According to the inundated and stopped clock found in the Iwama District, the tsunami inundation time is 15:38 JST, approximately one hour after the earthquake. A video clip was taken from the top of a building of the power plant located to the north of the Samegawa River. The clip recorded the arrival of the first tsunami at 15:33 which overflowed the seawall at 15:35 JST. The inundation level appeared to reach maximum by the second or the third tsunami which arrived at 15:40 JST, which is consistent with the time indicated by the stopped clock.

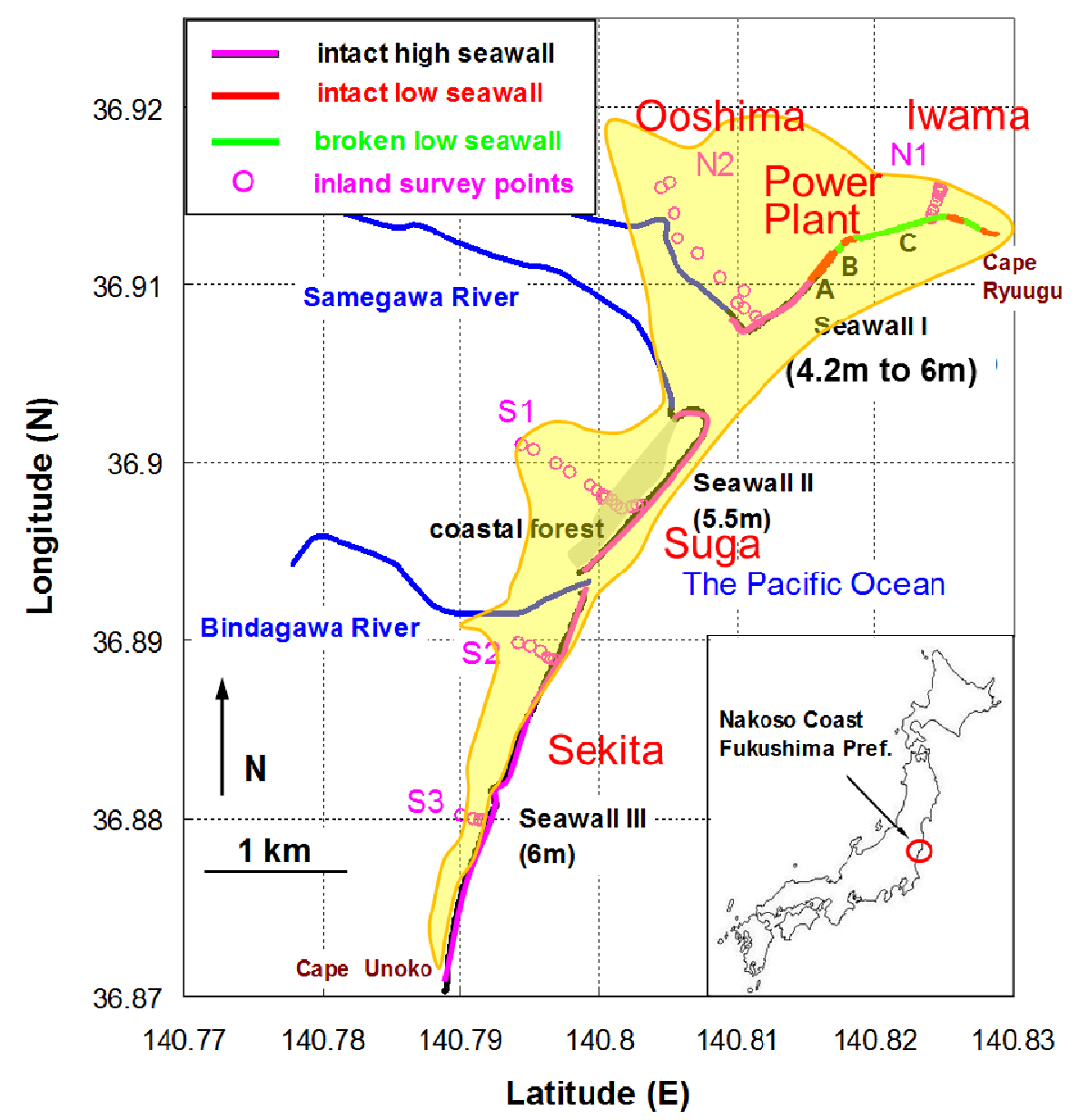

Figure 1. Field survey at the Nakoso Coast, Fukushima Prefecture, Japan; Yellow zone represents inundation. The coastal area is divided into five districts, Iwama, Power Plant, Ooshima, Suga and Sekita Districts

The instruments used in the field survey mainly include the Real-time Kinematic Global Positioning System (RTK-GPS), a handy GPS, a laser ranger and a measuring staff. The RTK-GPS presents the local elevation data in terms of Tokyo Peil standard (T.P., T.P. zero corresponds to the mean water level at the Tokyo Bay, which is the standard datum level for land topography in Japan). Hereafter, all the measured elevation data are referred to the T.P. standard. Spatial distribution of seawall height was measured with respect to the three sections as illustrated in Fig. 1, i.e., Seawall I 
corresponding to the north of the Samegawa River, Seawall II corresponding to the area between the Samegawa River and the Bindagawa River, and Seawall III corresponding to the south of the Bindagawa River. Subsequently, five survey lines behind the seawall, i.e., N1, N2, S1, S2 and S3 in Fig. 1 , were also considered to estimate the tsunami damping along the cross-shore direction.

Figure 2 illustrates the height of watermarks. The blue bar indicates inundation height and the white bar denotes run-up height. Tsunami heights near the shoreline are found to be 6 to $7 \mathrm{~m}$ T.P. except for smaller tsunami observed in the southernmost region. The smaller tsunami height in the south region is considered to be due to the sheltering effect due to the Cape Unoko and breakwaters of two fishery harbours located at the Cape Unoko.

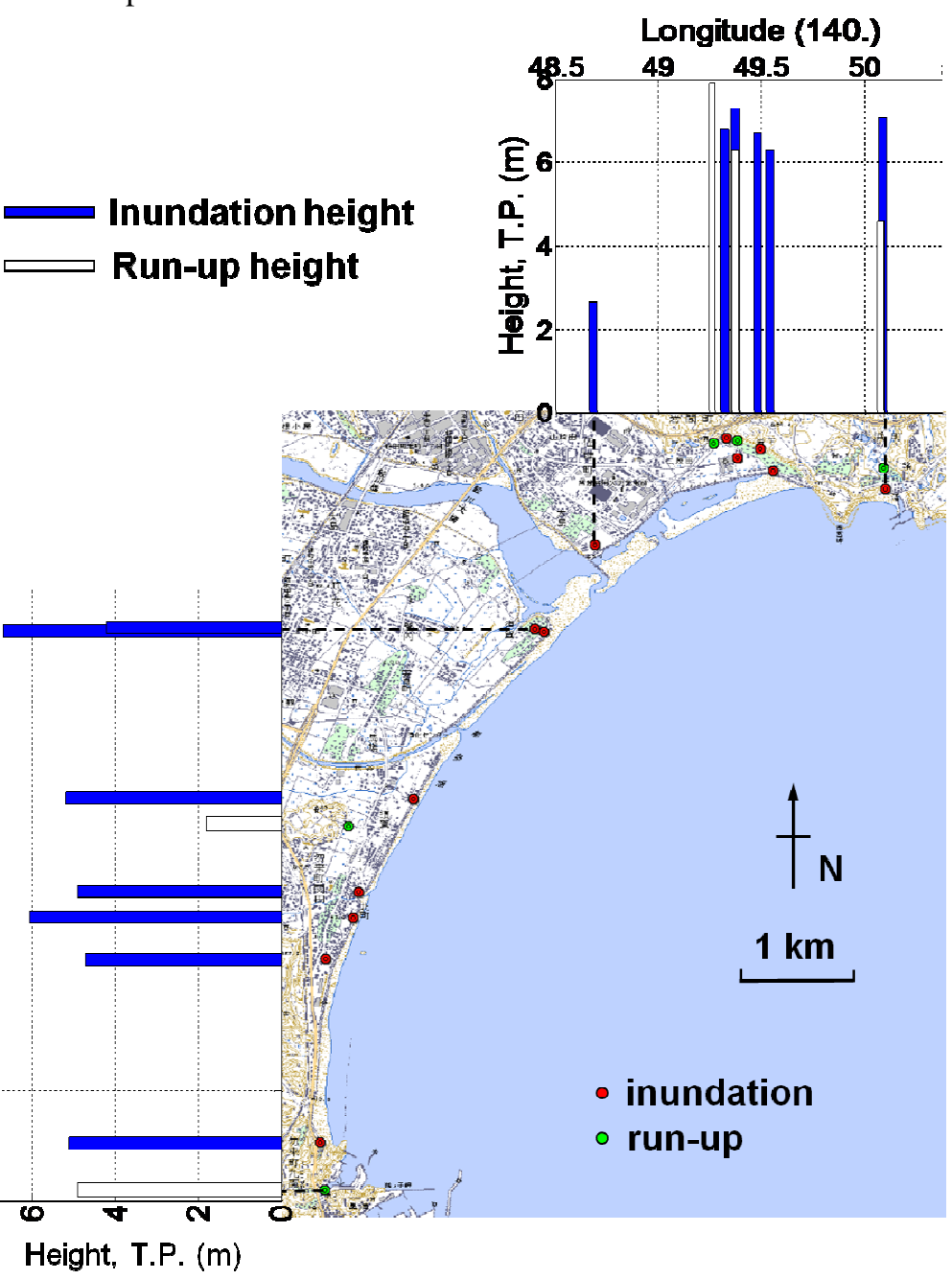

Figure 2. Distribution of tsunami watermark heights in the Nakoso Coast; The inundation height is 6 to $7 \mathrm{~m}$ except in the south region.

\section{North of the Samegawa River: Ooshima, Power Plant and Iwama Districts}

North of the Samegawa River was confirmed to be the most damaged region. A large amount of houses was washed away owing to the giant tsunami. Several parts of the seawall were also broken, which further deteriorated its function as a coastal defense structure to protect the human community behind. To demonstrate the relationship between the seawall height and tsunami damage, inspection on the damages of Seawall I was conducted and the result is presented in Figs. 1 and 3. Before tsunami, the Seawall I has a total length of $2 \mathrm{~km}$ with two different designed heights, i.e., $6 \mathrm{~m}$ on the south near the Samegawa River mouth with a length of $950 \mathrm{~m}$ (black line in Fig. 1), and about $4.2 \mathrm{~m}$ for the remaining part (red and green lines in Fig. 1). The height of the seawall was designed on the basis of run-up height calculation of storm waves since there are no large historic records of tsunami in this region. For the high seawall part, all kept intact after the tsunami attack; whereas, around $750 \mathrm{~m}$ long seawall (green lines in Fig. 1) was broken within the original low seawall section, i.e., $71 \%$ of the low seawall 
was collapsed. The measured spatial distribution of the post-tsunami seawall elevation in this region, starting from the Samegawa River mouth to the north, is demonstrated in Fig. 3. It is found the ground elevation is $5 \mathrm{~m}$ at the river mouth, which represents the Samegawa River bank height. Considering that the seawall height over here is $6 \mathrm{~m}$, the relative seawall height is only $1 \mathrm{~m}$. Moving north, the top of the seawall keeps the same height whereas the ground elevation decreases to $2.5 \mathrm{~m}$. Figure 4 shows the seawall in the Ooshima District. Although the ground level of the Ooshima District is as low as $+2 \mathrm{~m}$ T.P. and the tsunami overflowed the $6 \mathrm{~m}$ seawall, the damage was found to be insignificant. In this region, the seawall height was raised to the present $6 \mathrm{~m}$ after the overtopping of the high wave in 1950's. Figure 5 shows a typical damage behind the seawall. Although the parapet of the seawall remained intact there, some part of the concrete apron on the land side was broken with nearby land scoured by the overflowed tsunami.

At the location "A" in Fig. 3, the seawall height suddenly drops from $6 \mathrm{~m}$ to $4.2 \mathrm{~m}$. This is considered to be due to the presence of barrier sand bar in front of the north part of the beach, which damps the height of storm waves. Figure 6 (A) shows a panorama image taken at this location. Regarding to the status of pine trees, steel fence and pipeline on the rear side, it is easy to confirm the different performance of seawalls: behind the $6 \mathrm{~m}$ seawall, most local properties were conserved; on the contrary, significant damage developed on the lee side of the $4.2 \mathrm{~m}$ seawall with pine trees, fence and pipeline being ruined away. Further going north beyond the water gate, some seawall was broken and moved landward by the tsunami. The panorama photo Figure 6 (B) taken at location "B" in Fig. 3 presents the local situation there. Since the highest water level due to the tsunami at the seawall is more or less $7 \mathrm{~m}$ as we confirm in Fig. 2, it is considered that the criterion of the seawall collapse is in between $1 \mathrm{~m}$ and $2.8 \mathrm{~m}$ by the overflow depth. In this area, the relative seawall height keeps around $2 \mathrm{~m}$ with the ground elevation being around $2 \mathrm{~m}$. At location between 1,100 $\mathrm{m}$ and 1,600 $\mathrm{m}$ (in the vicinity of point " $\mathrm{C}$ " in Fig. 3), all seawalls were broken as revealed from Figure 6 (C). Some seawall blocks were even pushed across the road, and stay far away inland as shown in Figure 7. During the field survey, we found one broken seawall block lying on the ground $35 \mathrm{~m}$ landward from its original location. This concrete block has a dimension of 0.5 (upper boundary) $\times 1.7$ (lower boundary) $\times$ 2(height) $\times 10 \mathrm{~m}$ (length) with an estimated mass of approximate $53 \mathrm{ton}$, which vividly demonstrates the great power of the tsunami attack. At location 1,500 m north from the river mouth, it is found the ground elevation increases to $4 \mathrm{~m}$ at the north end as it approaches to the Cape Ryuugu. Correspondingly, the absolute seawall height increases to $5.6 \mathrm{~m}$ finally. Nevertheless, the relative seawall height decreases to $1.6 \mathrm{~m}$ at the end. Collapse of seawall is intermittent in this section which induced different damages to the backside community.

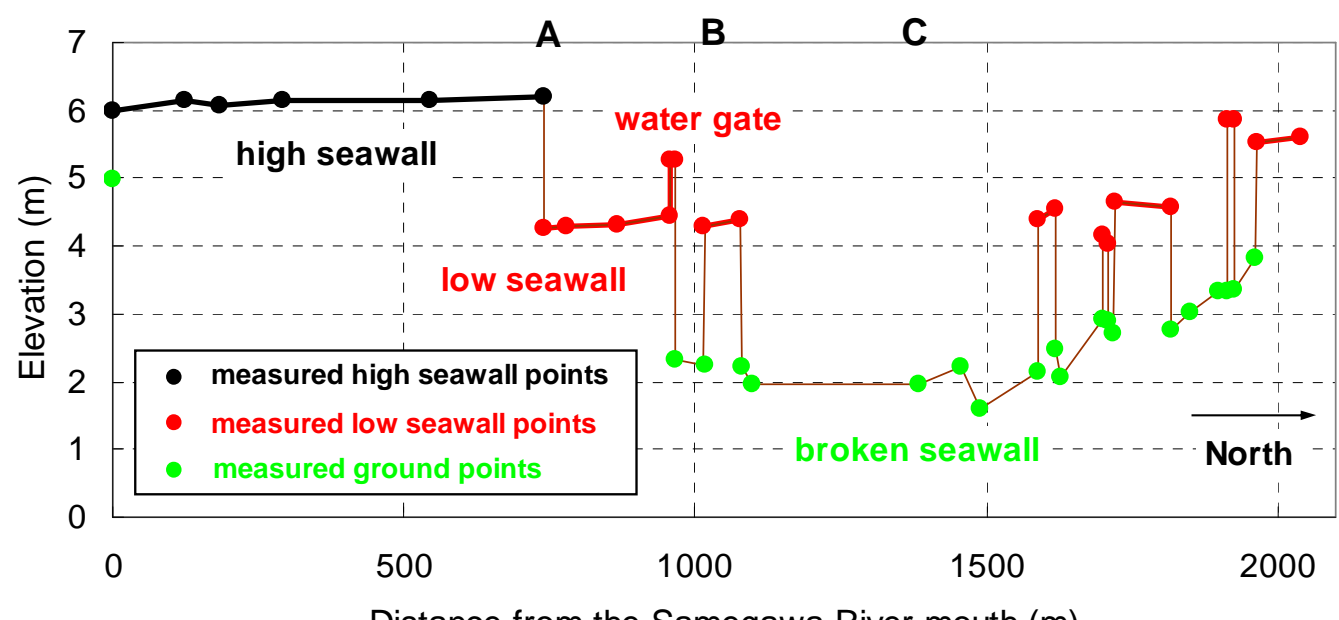

Figure 3. Spatial distribution of the post-tsunami seawall I and ground elevation on the north of Nakoso coast; The seawall height was discontinuous at Point A. Most of the lower seawall was broken. 


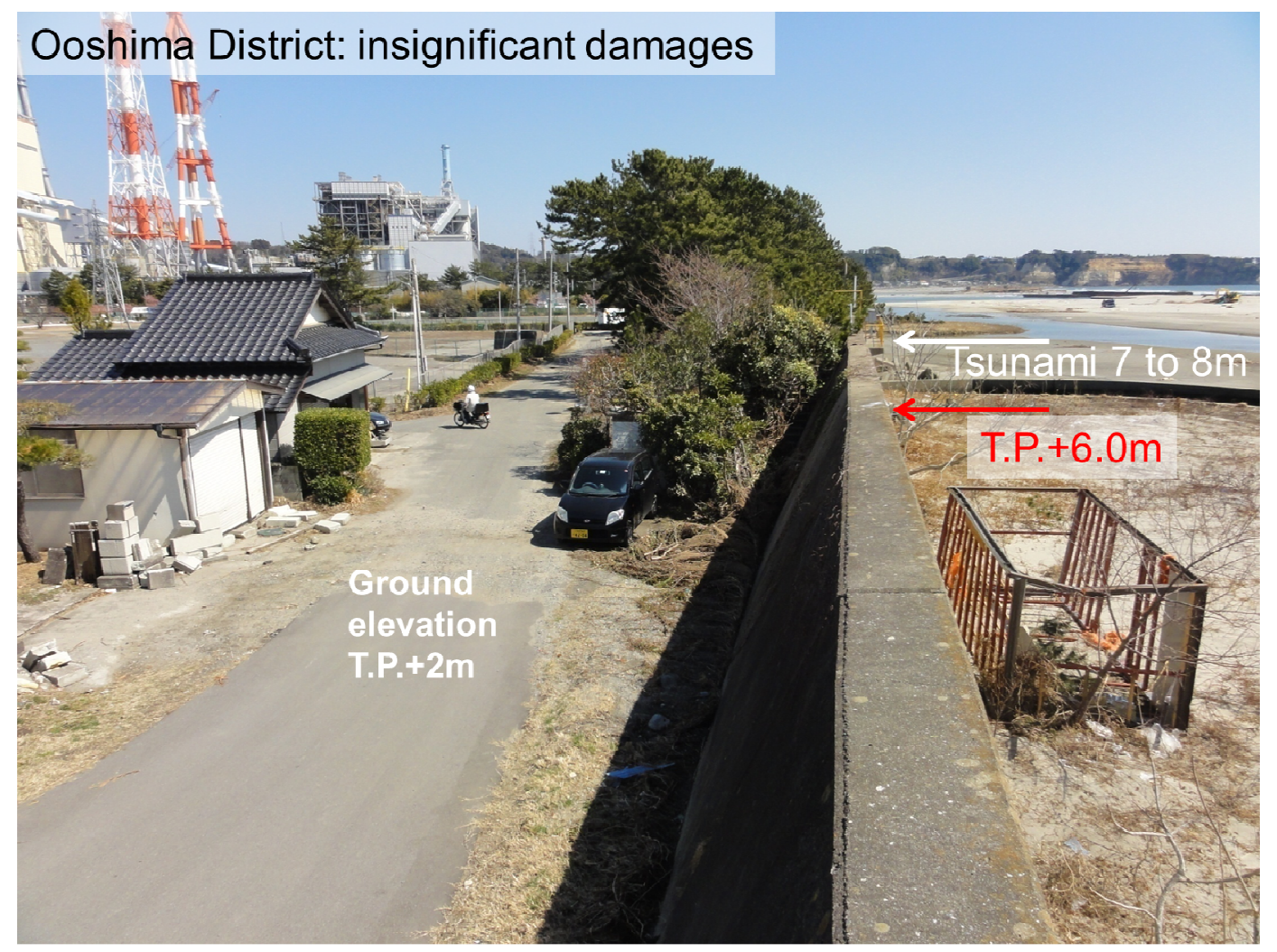

Figure 4. Insignificant damage behind a high seawall in Ooshima District. (March 25, 2011)

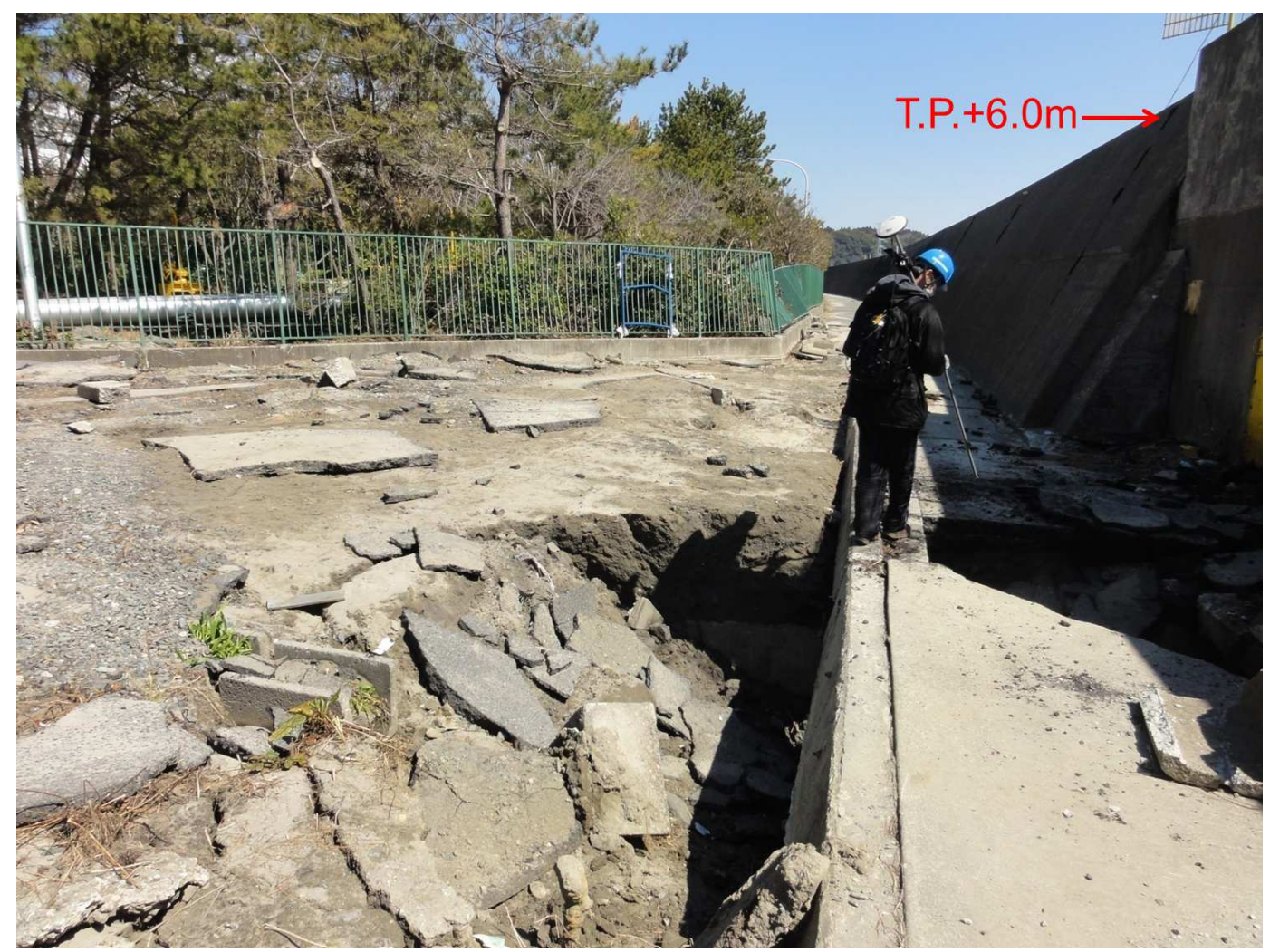

Figure 5. Intact parapet, apron concrete broken and land scoured by overflowed tsunami in Power Plant District. (March 25, 2011) 


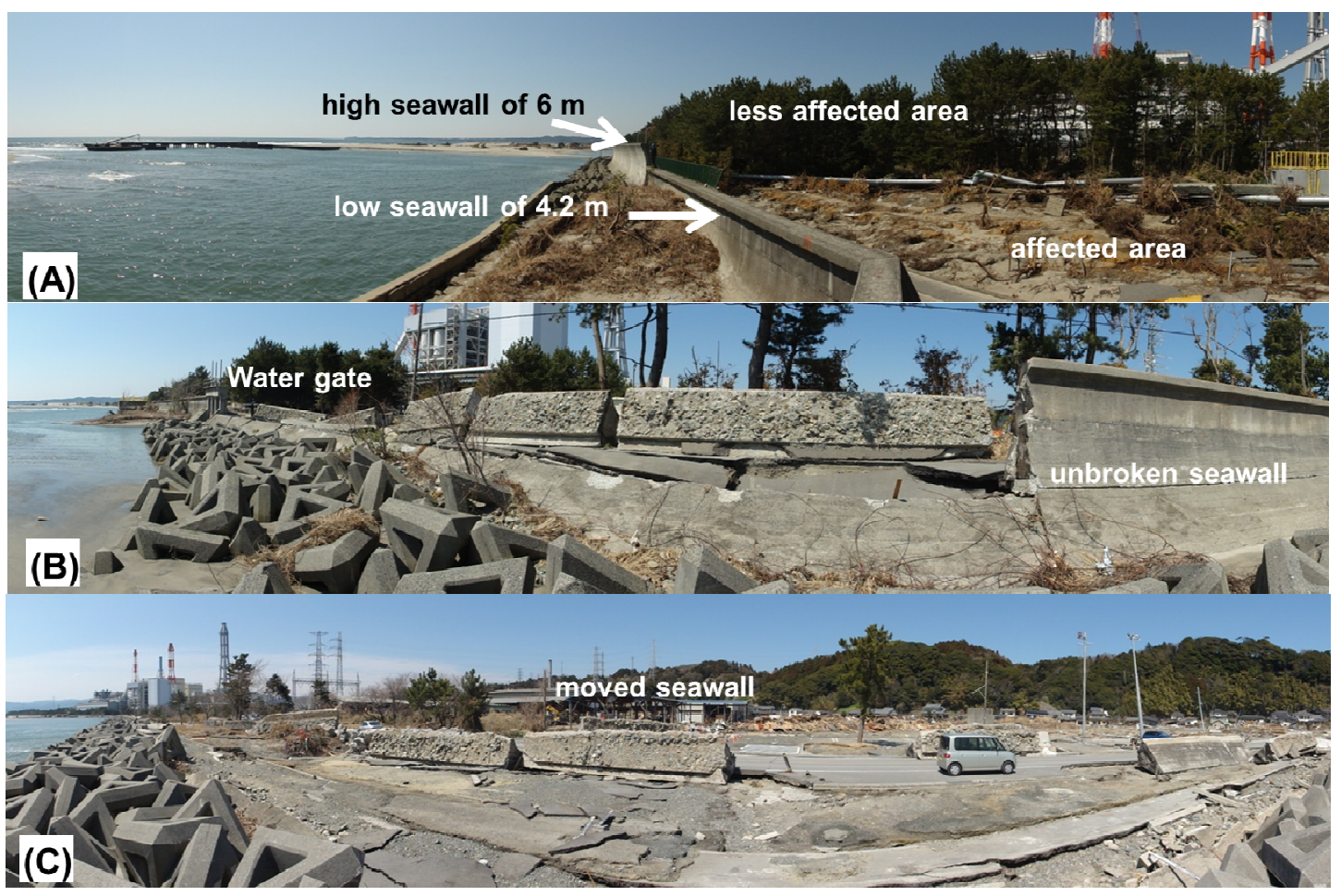

Figure 6. Panorama images taken at three specified locations (March 25, 2011, A, B and C indicated in Fig. 3)

Figure 8 describes tsunami damages to houses and seawalls in the area north to the Samegawa River mouth. Damages were identified by the comparison of two aerial photos taken by Geographical Information Authority of Japan, on March 12, 2011 and in 2009. Houses were marked as 'washed away' when the roof disappeared after tsunami at the original location found in the 2009 photo. The concrete blocks of the seawalls are denoted by white rectangles where they are found broken. The change in the shape of barrier sand bar located seaside of the seawall was also illustrated in the figure. The change in the shape of the barrier sand bar indicates that the barrier sand bar was deformed in the region where seawalls were broken severely. The barrier sand bar in front of the Ooshima District remained un-deformed. This is considered to be due to the concentration of tsunami return flow. Due to the difference in the spatial slope of the water surface, tsunami up-rush would overflow the seawall almost uniform in a relatively short time, on the other hand, receding tsunami would tend to concentrate to the area with low elevation or to the river mouth in relatively long durations. The monitoring of the recovery of the barrier sand bar is important since the presence of the barrier sand bar is essential to the run-up of storm waves and thus influential to the height of seawall .

According to the testimony of local residents in the Iwama District who observed tsunami during their evacuation, the first and the second tsunami overflowed the seawall and flowed to the south, that is, to the direction of the Power Plant. The third tsunami, however, came from the south and washed away the northern residential area. This is consistent with our survey in which we found road signs and electricity poles were mostly bent to the south as shown in Figure 9. This is also consistent with the video clip taken from the top of a building in the Power Plant. 


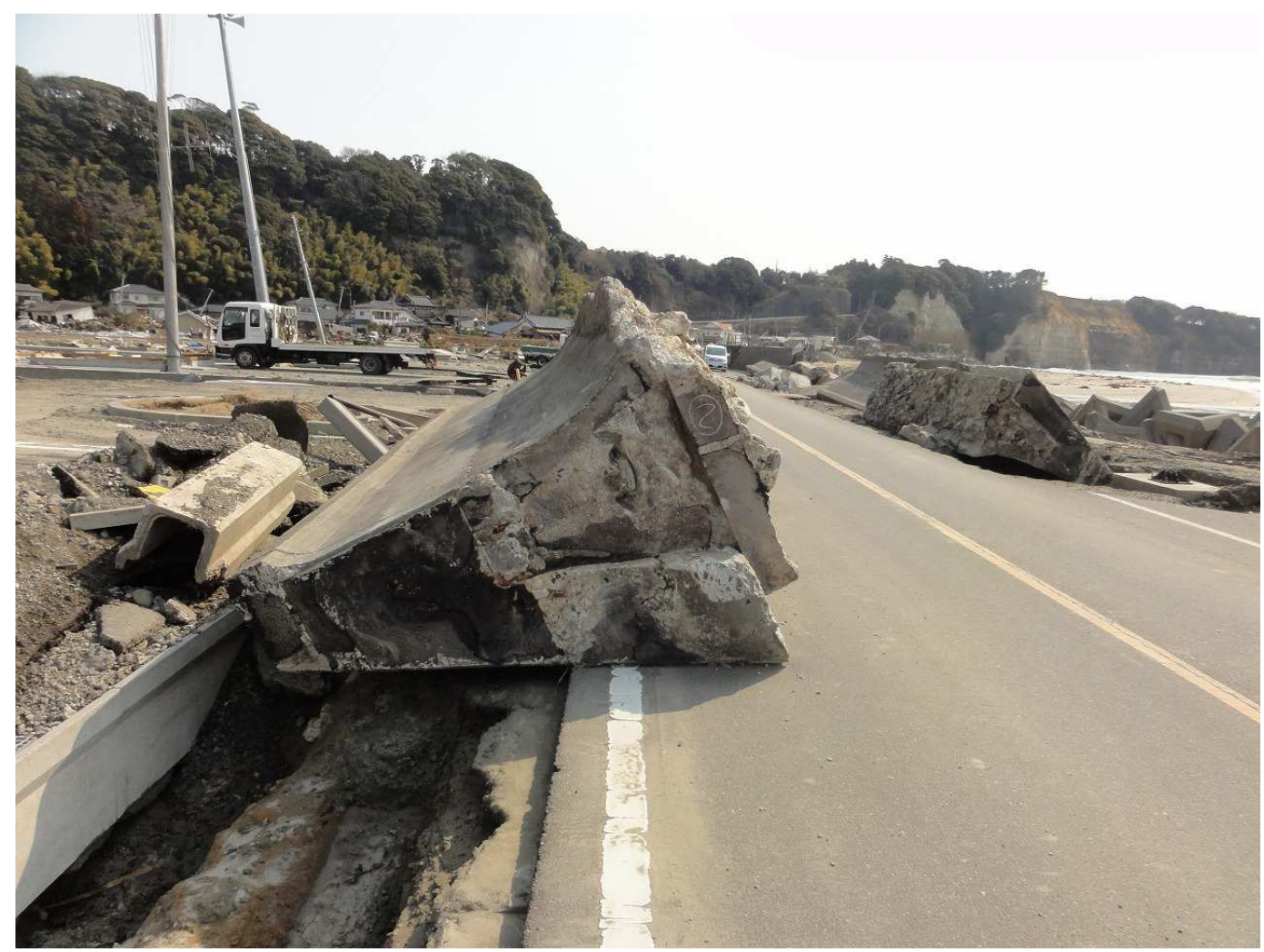

Figure 7. Broken and moved parapet of a seawall in Iwama District (March 25, 2011) 


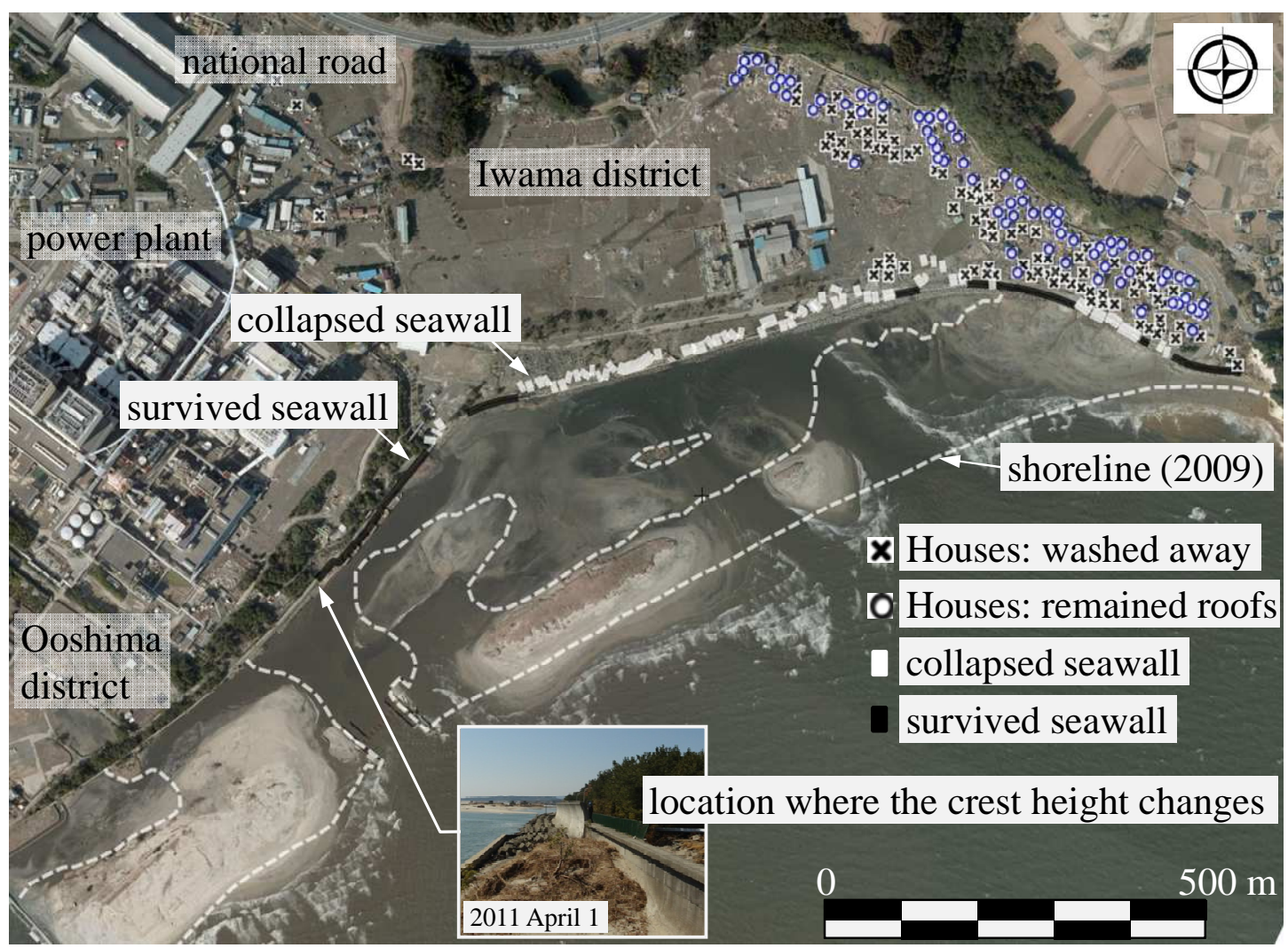

Figure 8. Tsunami damage in Iwama District, presenting disappeared houses, collapsed seawall and deformed barrier sand bar; Most of the houses were washed away in the Iwama District. Broken seawall block was transported inland. 


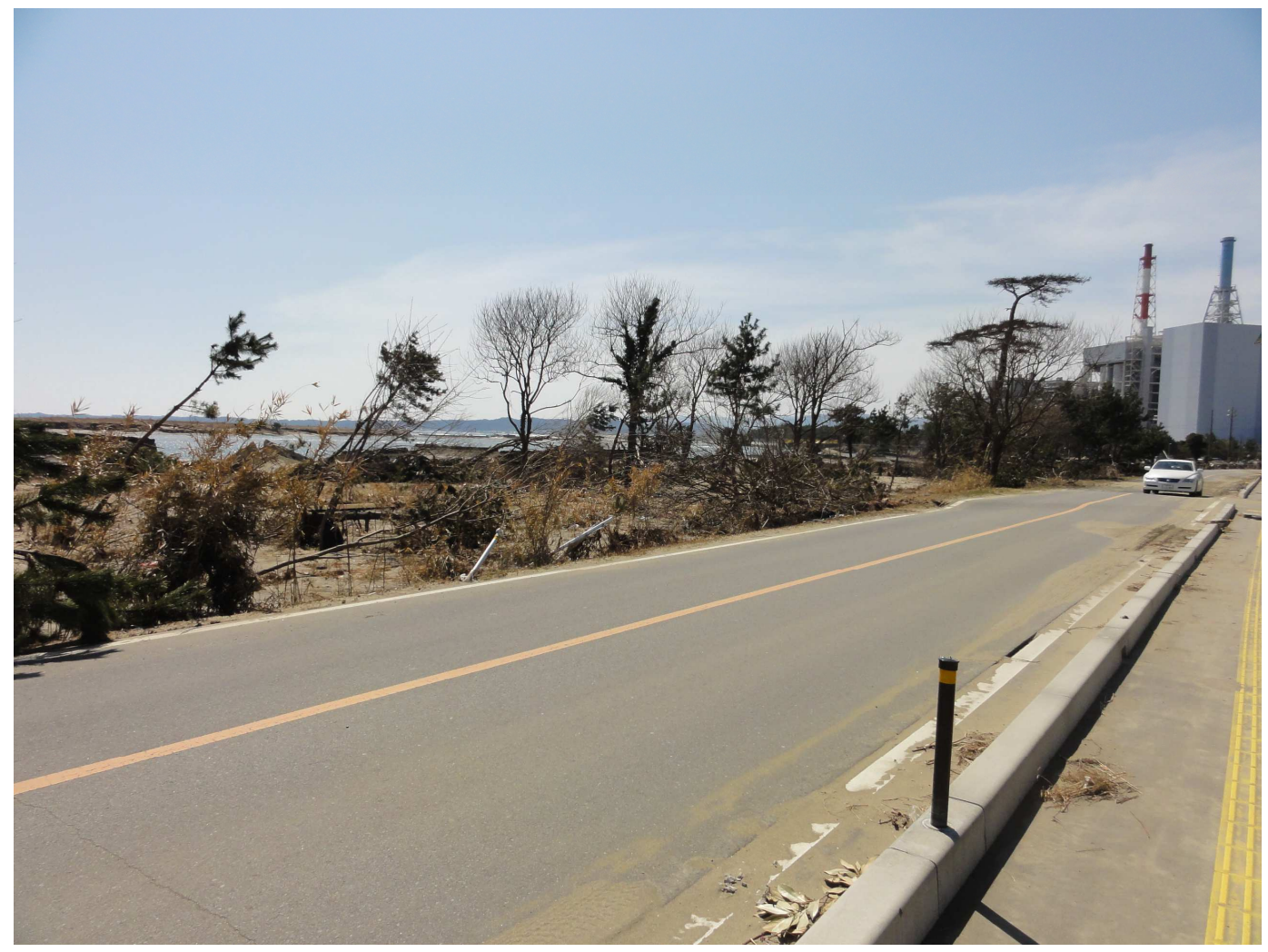

Figure 9. Fallen trees and road signs, representing the southward flow of the tsunami (March 25, 2011)

Figure 10(a) presents the cross-shore distribution of the ground elevation and tsunami inundation height at survey lines N1 and N2. Along the line N1, the seawall has a height of $4.5 \mathrm{~m}$ and the nearby ground elevation is $2.5 \mathrm{~m}$. Moving to the landward direction, the ground elevation gradually increases. At location $210 \mathrm{~m}$, the ground elevation is $5.4 \mathrm{~m}$, about $3 \mathrm{~m}$ higher than the ground level at the seawall. The measured inundation height is $7.3 \mathrm{~m}$ ( $4.7 \mathrm{~m}$ above the local ground level) at location $137 \mathrm{~m}$. In the vicinity of broken seawall, the inundation height is only about $6.3 \mathrm{~m}$ as is confirmed in Figure 2 . At the same time, tsunami inundation height is $6.7 \mathrm{~m}$ at location $210 \mathrm{~m}$. Therefore, the following scenario can be drawn from Fig. 10(a) with respect to line N1: After tsunami passed through the seawall, the tsunami height increases by $1 \mathrm{~m}$ within a cross-shore distance of $150 \mathrm{~m}$ owing to the run-up motion on the sloping topography (high tsunami velocity can be estimated since over here, most of the houses were washed away). Subsequently, inundation height decreases by $0.6 \mathrm{~m}$ from $150 \mathrm{~m}$ to $210 \mathrm{~m}$. This is ascribed to the fact that tsunami wave may have lost its energy due to the significant bottom friction by the presence of dense houses.

Along line N2, the local seawall has a height of $6.2 \mathrm{~m}$ and the nearby ground elevation is $2.6 \mathrm{~m}$. Moving to the landward, there is no significant change on the ground elevation with a certain decrease by $1 \mathrm{~m}$ just after the seawall. Considering the inundation height, it is around $2.6 \mathrm{~m}$ for all measured points (the inundation depth is approximate $0.6 \mathrm{~m}$ ). Confirmed from the local residents, although the overflowed tsunami inundated the residential area, the tsunami intensity/velocity was significantly mitigated/reduced because of the protection of the high seawall. Therefore, the damage to the local houses is fairly mild. Increase of the water level in this district is assumed to be inch by inch and spatially uniform. However, the inundated area is large here, which covers more than $1 \mathrm{~km}$ landward of the seawall, whereas due to the steep slope of the land topography, the final tsunami run-up at line N1 is only about $330 \mathrm{~m}$ away from the seawall. 

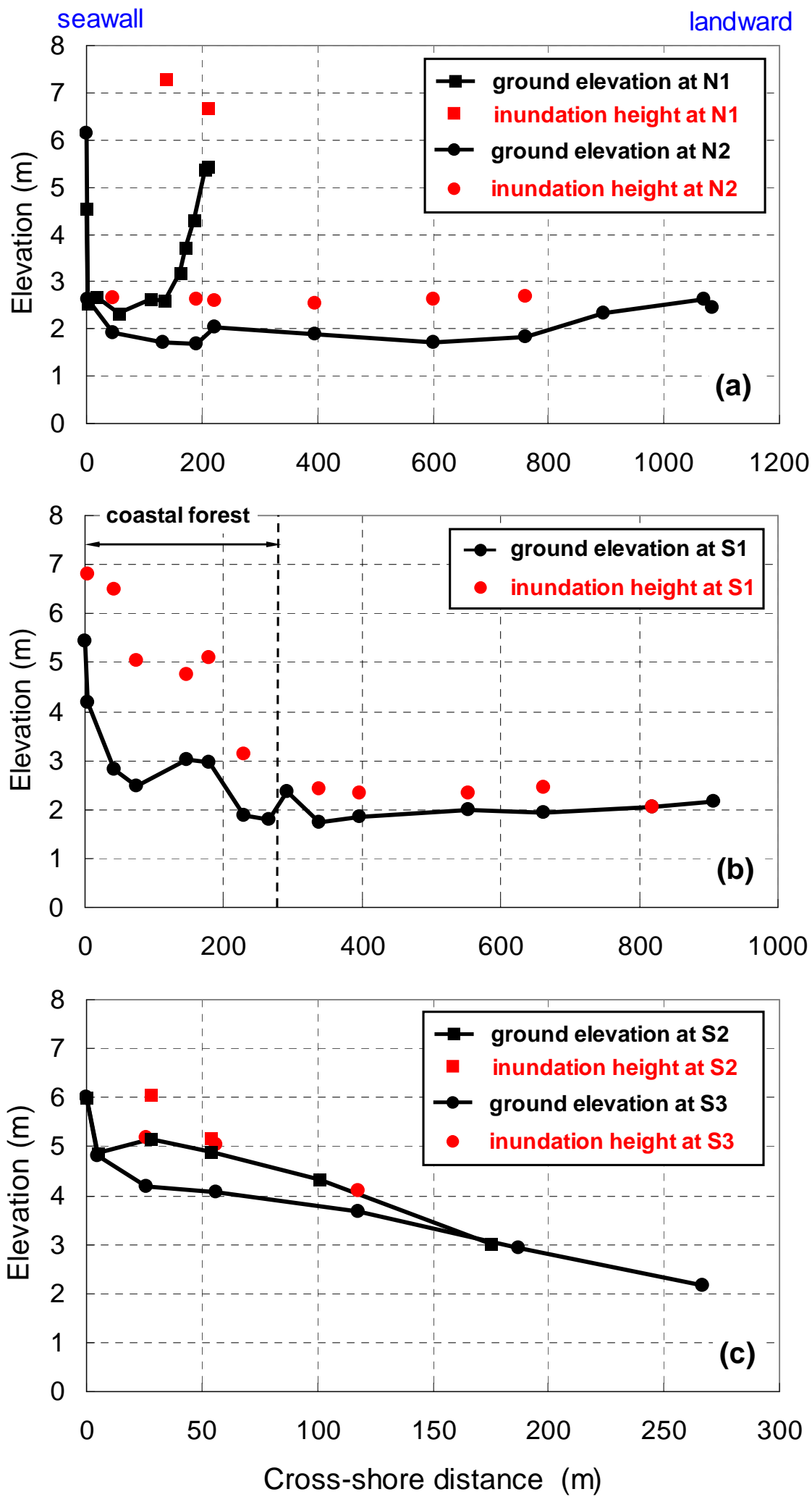

Figure 10. Cross-shore distribution of ground elevation and tsunami inundation height at survey lines N1 \& N2 (a), S1 (b) and S2 \& S3 (c). 


\section{Region between the Samegawa River and the Bindagawa River: Suga District}

In this coastal region, only the north part is covered by the human community and the remaining is the coastal forest zone as shown by the shadow area in Fig. 1. As for this area, the whole seawall, i.e., Seawall II with a height of $5.5 \mathrm{~m}$, survived from the tsunami attack although certain overflow occurred. Figure 11 shows damage to a house in Suga District, where watermark was found at the ceiling of the first floor, at the height of $6.7 \mathrm{~m} \mathrm{T.P.}$

In the field survey, we found that the tsunami flooding was developed at the junction between the river bank and the seawall. Figure 12 shows a typical location where tsunami overflowed the river bank. The reason appeared to be due to the difference in structural type, that is, river bank is basically soil embankment partly covered with concrete plates on the riverside while seawall is covered with concrete plates on the three sides, i.e., seaside, landside and top.

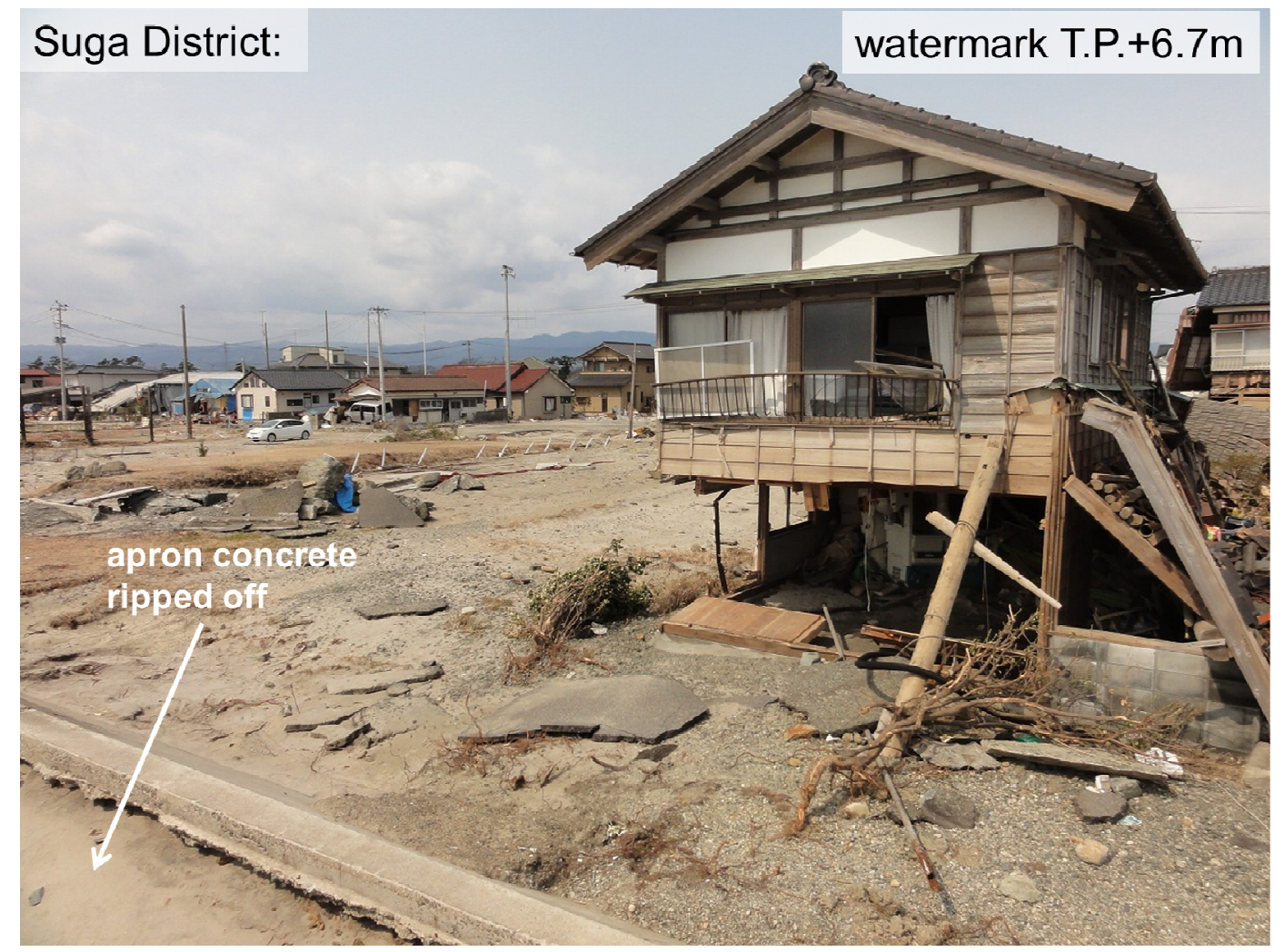

Figure 11. Broken seawall and a house in Suga District. (March 25, 2011) 


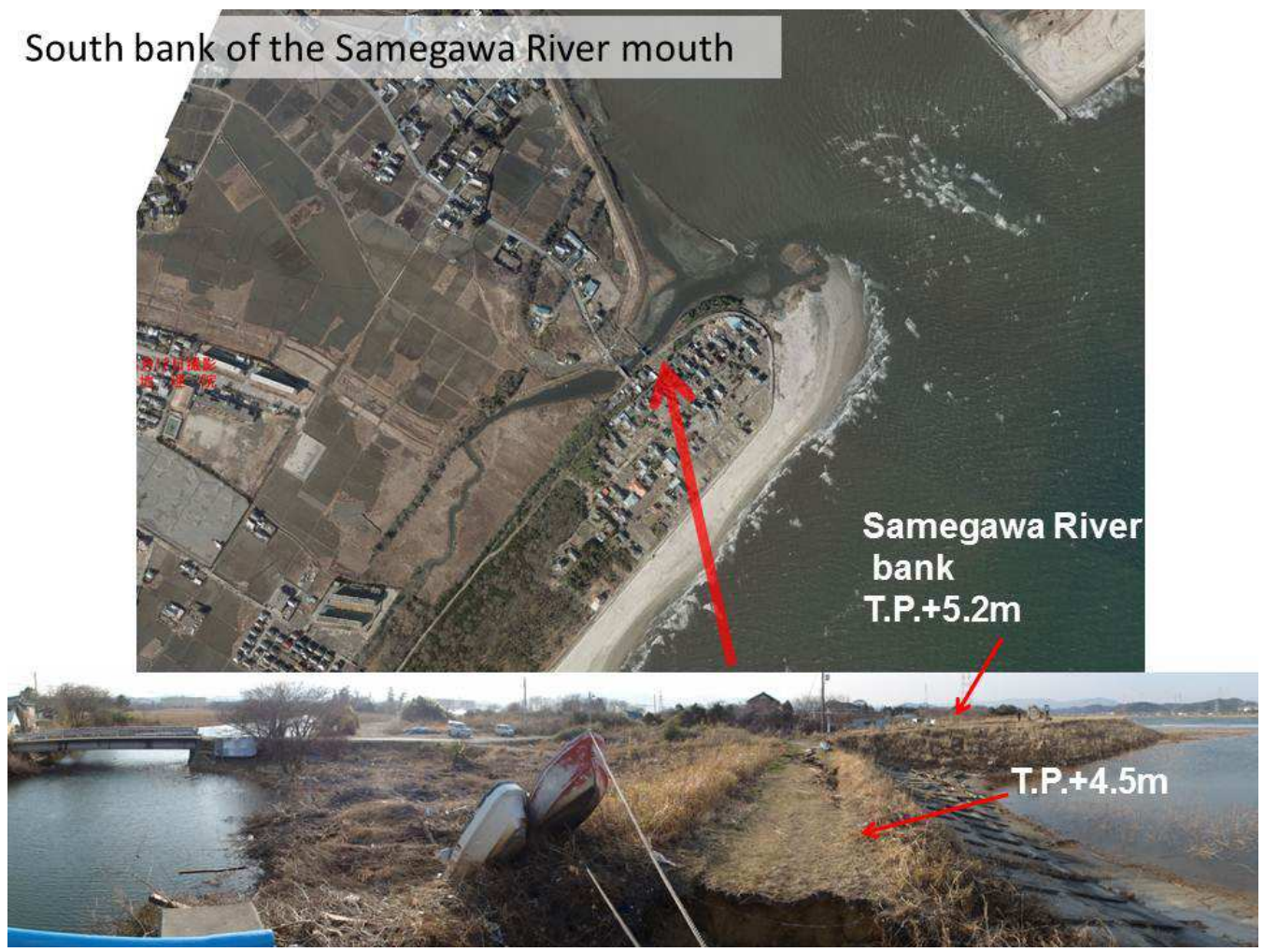

Figure 12. Inundation from broken river bank connected to intact seawall. (April 1, 2011)

Figure 10(b) illustrates the cross-shore distribution of the ground elevation and tsunami inundation height at the survey line S1, which crosses the coastal forest zone as demonstrated in Fig. 13. The local seawall has a height of $5.5 \mathrm{~m}$ whereas the nearby ground elevation is $4.2 \mathrm{~m}$ (the relative seawall height is $1.3 \mathrm{~m}$ ). Moving landward up to the $260 \mathrm{~m}$ location, the ground elevation decreases to $1.8 \mathrm{~m}$. At the same time, the tsunami inundation height also drops significantly in this region, i.e., from $6.8 \mathrm{~m}$ near the seawall to $3 \mathrm{~m}$ at the $230 \mathrm{~m}$ location. The function of coastal forest as a buffer zone against the tsunami attack, which increases the friction, is obviously demonstrated in this figure. Further beyond, the ground level keeps around $2 \mathrm{~m}$ and the corresponding inundation depth is $0.5 \mathrm{~m}$. During the field survey, we confirmed that the damage in this area was minor which indicates the tsunami velocity in this area is also small due to the reduction of tsunami intensity from the coastal forest. The most inland run-up location was found at location $820 \mathrm{~m}$ from the seawall. 


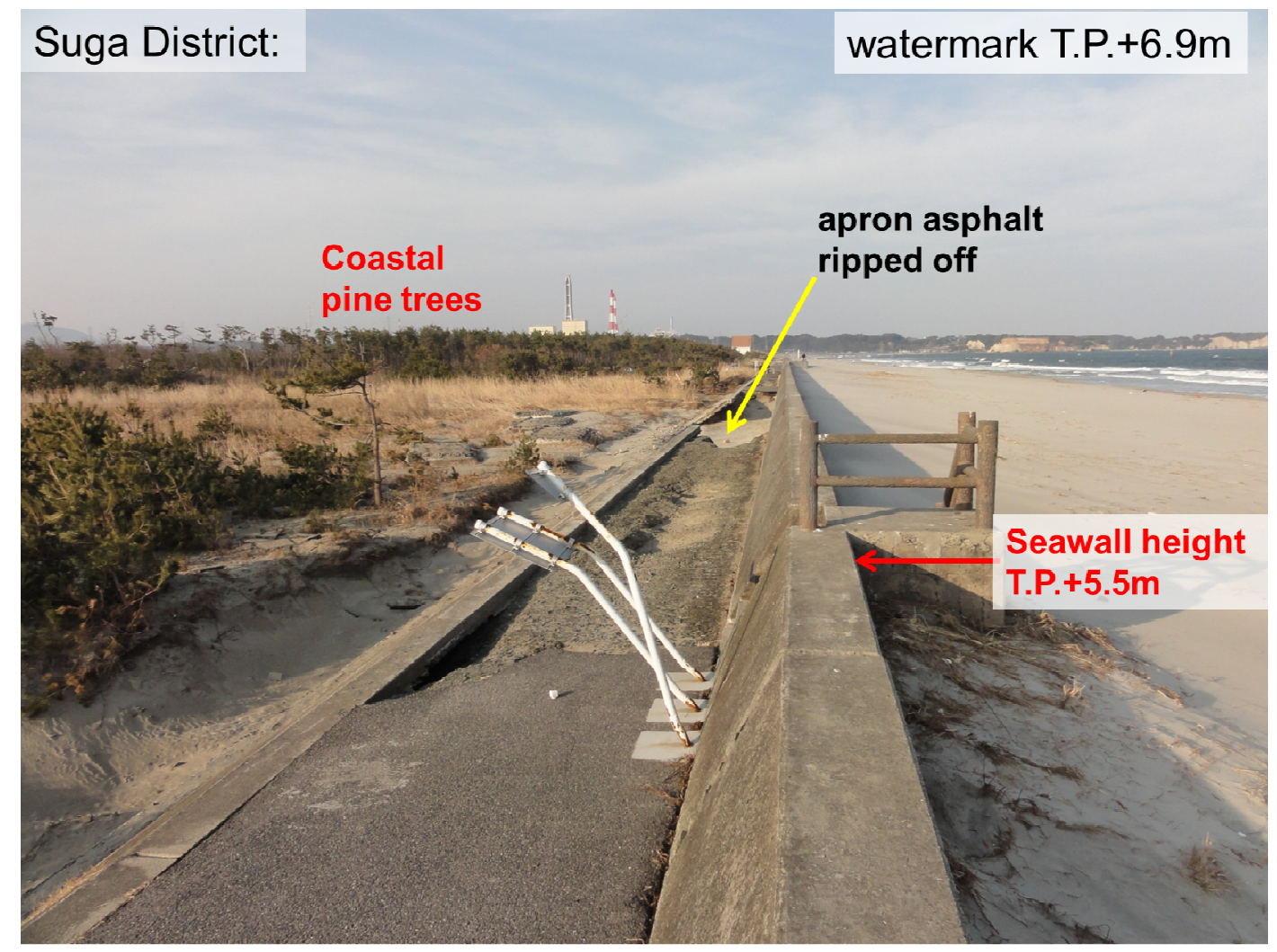

Figure 13. Partially broken seawall and coastal pine trees in Suga District. (April 1, 2011)

\section{South of the Bindagawa River: Sekita District}

Tsunami damage in this region is the mildest within the present study area, which is ascribed to the robust (all survived) and high seawall with a height of $6 \mathrm{~m}$. In which, the $1.3 \mathrm{~km}$ long enhanced seawall just south of the Bindagawa River is constructed in 2006. Figures 10(c) demonstrates the cross-shore distribution of ground elevation and tsunami inundation height at survey lines S2 and S3. It is clear that the local seawall height is $6 \mathrm{~m}$ at these two locations with a relative seawall height being $1.2 \mathrm{~m}$. Moving landward, the ground elevation decreases. The inundation depth near the seawall is about $1 \mathrm{~m}$, which decreases to $0.4 \mathrm{~m} 120 \mathrm{~m}$ landward along the line $\mathrm{S} 2$, and to $0.3 \mathrm{~m} 50 \mathrm{~m}$ landward along the line $\mathrm{S} 3$. Tsunami intensity was weakened in this area accompanying with the flooding. Certain damage to the concrete road and human properties can be confirmed in this region. However, comparing with the region north of the Samegawa River, the situation here is much better. Relatively high elevation of land topography as confirmed in Figure 10(c) is considered to be another reason of minor damages.

Figure 14 illustrates a location where exceptional tsunami damage was observed in this region. It is a location where the seawall was curved concave to the sea, at the river mouth of a small river. The concaved seawall appeared to concentrate the tsunami energy at the river mouth, where the apron concrete of the seawall was broken and houses located behind the seawall were affected by overflowed tsunami. The watermark was measured at $4.9 \mathrm{~m}$ T.P. 

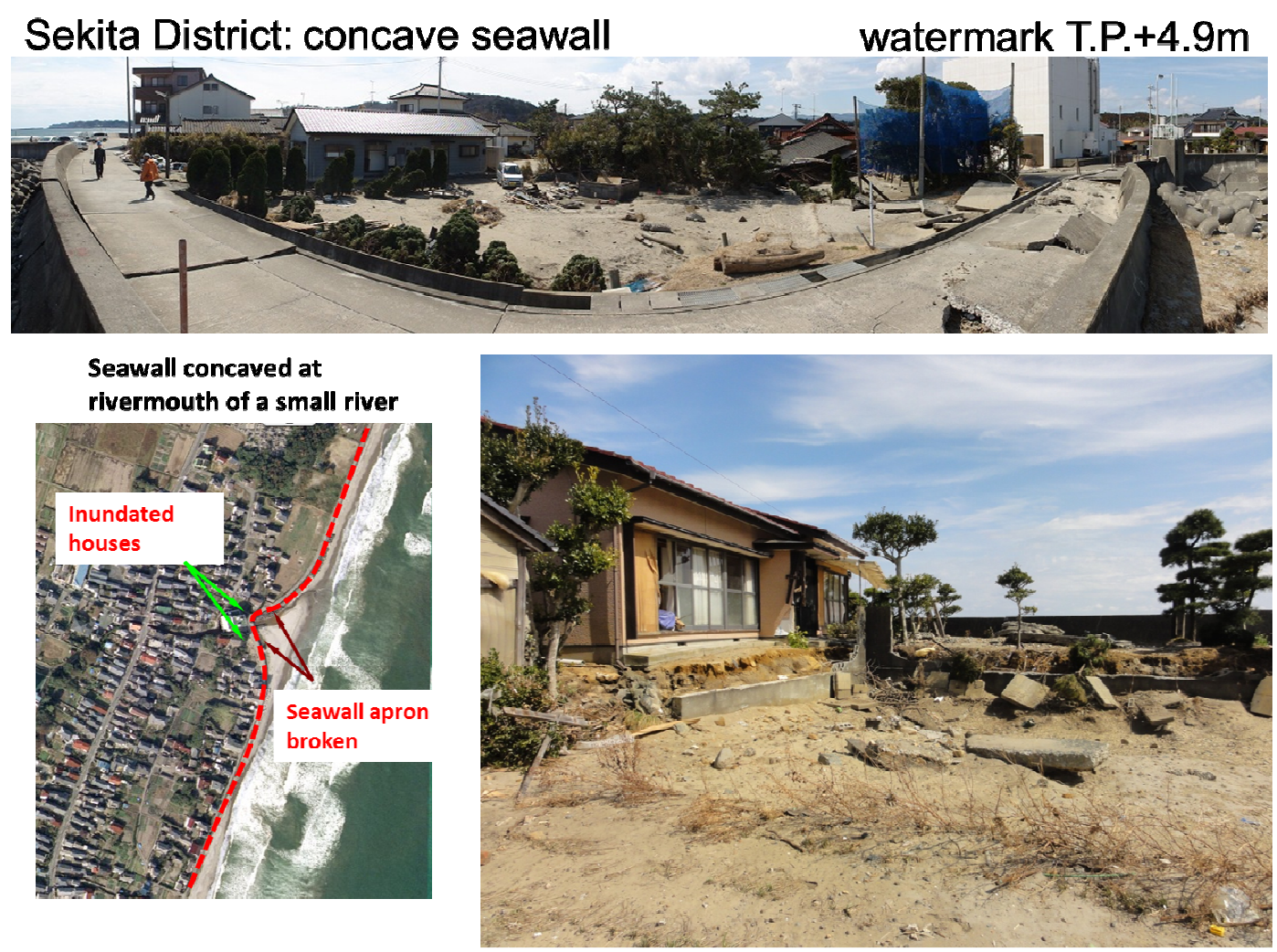

Figure 14. Damage concentrated to a concave seawall in Sekita District. (March 24, 2011)

\section{Concluding Remarks}

Through the post-tsunami survey, we found that at the Nakoso Coast, Fukushima Prefecture, Japan, tsunami damage showed a sharp contrast depending on the height of seawall. A relatively high seawall with height $6 \mathrm{~m}$ in this region did safeguard the coastal human properties; whereas, $71 \%$ of the low seawalls with height $4.2 \mathrm{~m}$ were broken during the tsunami attack and the catastrophic disaster developed in the corresponding sheltered area. A clear difference at the boundary of these two types of seawalls is observed. Behind the $6 \mathrm{~m}$ seawall, the tsunami intensity and velocity were significantly reduced and the inundation depth is only $0.6 \mathrm{~m}$. Nevertheless, tsunami intensity was enhanced in the seawall-broken area with an inundation depth of $4.7 \mathrm{~m}$. In the middle region between the Samegawa River and the Bindagawa River, $5.3 \mathrm{~m}$ high seawall survived from the tsunami attack. We also confirmed that the coastal pine tree forest, serving as a buffer zone, played a significant role against the tsunami attack, which reduced the tsunami height approximately by $4 \mathrm{~m}$ within a cross-shore distance of $230 \mathrm{~m}$. South of the Bindagawa River, the tsunami damage is the mildest due to the robust $6 \mathrm{~m}$ high seawall and relatively high land topography.

It is to be noted here that the damage in the Nakoso Coast is significant in the north region of a pocket beach. Similar damage distributions were found in the southern part of the east Japan coasts facing the Pacific Ocean, such as Ooarai in Ibaraki Prefecture, and Asahi in Chiba Prefecture. In these areas, damages were found significant on the south region of a cape. Since the epicenter of the earthquake is located north, these areas are expected to be sheltered by the cape on the north. The reasons for the tsunami amplification can be considered as follows: (1) Tsunami concentrated behind the cape owing to the convex offshore bathymetries around the cape. Refraction of tsunami will be developed in the deep sea up to $1,000 \mathrm{~m}$ depth contours while usual short waves will not be refracted by such bathymetry. (2) The height of seawalls tends to be decreased since the width of the beach tends to be wide there. The run-up height calculation will become smaller due to the presence of such wide beach. (3) Edge waves could be excited in the pocket beach and amplified near the cape which is a reflective boundary. Further studies based on numerical models of tsunami propagation should be expected to identify the mechanisms of tsunami amplification. 


\section{ACKNOWLEDGMENTS}

A part of this study was supported by a GRENE Project, "Design of resilient land based on environmental information technology", funded by the Ministry of Education, Culture, Science and Technology.

\section{REFERENCES}

Sato, S., T. Kajimura, M. Abe, M. Isobe. 2004. Sand movement and long-term beach evolution in a fluvial system composed of the Samegawa River and the Nakoso Coast, Coastal Engineering Journal, 46(2), 219-241.

Tohoku Earthquake Tsunami Information. 2011. http://www.coastal.jp/tsunami2011/ 